\title{
ANALYSIS OF BIOACTIVE COMPONENTS FROM CHLOROFORM EXTRACT OF LYCOPERDON SP. (APIOPERDON)
}

\author{
BHARATHNAIR*, DELMY ABRAHAM, K. SARANYA, G. E. MALLIKARJUNASWAMY
}

Department of Forest Pathology, Kerala Forest Research Institute, Peechi, Thrissur, Kerala. Email: bharathleo5@gmail.com Received: 07 October 2020, Revised and Accepted: 23 november 2020

\section{ABSTRACT}

Objective: The present work was done to find out various bioactive compounds present in the chloroform extract of Lycoperdon pyriforme using gas chromatography-mass spectrometry (GC-MS).

Methods: L. pyriforme was collected cleaned to remove any dirt and oven dried at $60^{\circ} \mathrm{C}$. The sample was then finely powdered and extracted with chloroform using Soxhlet apparatus. The chemical composition of chloroform extract was then analyzed using QP2010S-Shimadzu GC-MS instrument.

Results: Chloroform extract resulted in the presence of 33 compounds with 1-Heneicosanol (11.17\%) and E-15-Heptadecenal (11.08\%) forming major compounds and 1-Tetradecanol (0.16\%), Dichloroacetic acid, and decyl ester $(0.15 \%)$ forming least.

Conclusion: The results indicated the presence of a variety of compounds thus providing the information about various bioactive compounds present in Lycoperdon sp. and its further application in the field of pharmacology.

Keywords: Lycoperdon pyriforme, Chloroform extract, Gas chromatography-mass spectrometry.

\section{INTRODUCTION}

Fungi besides being pathogens are also known to possess medicinal values. Since ancient times mushrooms, visually distinctive compared with other class of fungi with naked fruiting bodies, have been used in traditional medicines as "the ultimate health food" [1]. Their medicinal characteristics have led them to be used in the field of drug development. A number of mushrooms have been screened for their antimicrobial potential for their use in pharmacology [2-5].

Lycoperdon otherwise "puffballs" a saprobe belongs to the family Agaricaceae. They are widely distributed in tropics growing on various habitats, on tree stumps, on decaying logs, and on ground among fallen leaves [6]. A number Lycoperdon species have been tested for their antimicrobial potentiality [7]. The present work has been carried out to understand various bioactive compounds present in Lycoperdon pyriforme In the present study, chloroform extract has been used and various compounds are detected using gas chromatography-mass spectrometry (GC-MS) technique.

\section{MATERIALS AND METHODS}

\section{Fungal specimen and extraction}

L. pyriforme (Schaeff.) Vizzini (Apioperdon pyriforme) (Fig. 1) was collected from in and around the Kerala Forest Research Institute campus. The specimen was identified and confirmed by referring standard manual [8]. The specimen was cleaned to remove any dirt and was then oven dried at $60^{\circ} \mathrm{C}$. The dried specimen was then pulverized to fine powder in a mechanical grinder. The powder was weighed and then subjected to Soxhlet extraction using chloroform. The extract was concentrated using rotary evaporator. Thus obtained final residue was subjected to GC-MS analysis.

\section{GC-MS analysis}

GC-MS analysis was carried out using QP2010S-Shimadzu GC-MS instrument $(30 \mathrm{~m} \times 0.25 \mathrm{~mm} \times 0.25 \mu \mathrm{m}$, Rxi-5Sil MS). One microliter of the chloroform extract was injected into the GC-MS instrument. Initially, the column temperature was maintained at $80^{\circ} \mathrm{C}$ for $2 \mathrm{~min}$, followed by a temperature gradient from $80^{\circ} \mathrm{C}$ to $260^{\circ} \mathrm{C}$ and held constant for
$10 \mathrm{~min}$ and finally raised temperature to $280^{\circ} \mathrm{C}$ and held constant for $6 \mathrm{~min}$. The instrument operated in a split mode and libraries used for analysis was NIST 11 and WILEY 8.

\section{RESULTS AND DISCUSSION}

GC-MS analysis of chloroform extract of $L$. pyriforme showed the presence of 33 different compounds. The active compounds with their retention time, area, area percentage, height, height percentage, base $\mathrm{m} / \mathrm{z}$, and their names are presented in Table 1 . The GC-MS chromatogram of the chloroform extract is shown in Fig. 2. About 33 compounds have been found in which 1-Heneicosanol (11.17\%) and E-15-Heptadecenal $(11.08 \%)$ are the major compounds and Dichloroacetic acid, decyl ester $(0.15 \%)$, and 1-Tetradecanol $(0.16 \%)$ formed minor compounds in the chloroform extract. Besides, a number of compounds such as E-14Hexadecenal, Phenol, 2,4-bis(1,1-Dimethylethyl)-, n-Tetracosanol-1, Ergosterol, Ergosta-7,22-Dien-3-ol, and (3.Beta.,22E)- are also present in fairly large amounts which gives Lycoperdon sp. its antibacterial

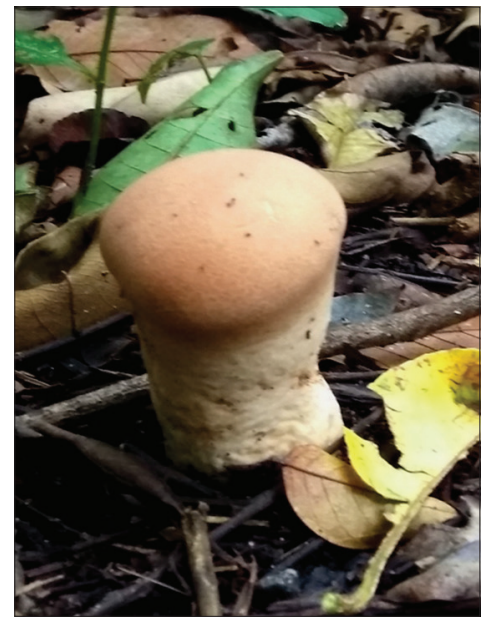

Fig. 1: Lycoperdon pyriforme (Apioperdon pyriforme) 
Table 1: Compounds detected in the chloroform extract of Lycoperdon pyriforme

\begin{tabular}{|c|c|c|c|c|c|c|c|}
\hline Peak\# & R.Time & Area & Area\% & Height & Height $\%$ & Name & Base $\mathbf{m} / \mathbf{z}$ \\
\hline 1 & 5.532 & 392251 & 0.80 & 146463 & 0.57 & 2-Pyrrolidinone & 85.05 \\
\hline 2 & 7.413 & 109389 & 0.22 & 73947 & 0.29 & 1-Dodecene & 55.05 \\
\hline 3 & 8.313 & 2183095 & 4.43 & 477122 & 1.86 & Benzeneacetic acid & 91.10 \\
\hline 4 & 10.276 & 2427813 & 4.92 & 1730368 & 6.74 & 1-Tetradecene & 55.05 \\
\hline 5 & 10.383 & 219369 & 0.44 & 164541 & 0.64 & Tetradecane & 57.05 \\
\hline 6 & 10.876 & 112748 & 0.23 & 75686 & 0.29 & 4'-(2-Methylpropyl)acetophenone & 161.15 \\
\hline 7 & 11.786 & 3780013 & 7.67 & 2414673 & 9.40 & Phenol, 2,4-bis(1,1-Dimethylethyl)- & 191.20 \\
\hline 9 & 12.909 & 304523 & 0.62 & 222487 & 0.87 & Hexadecane & 57.05 \\
\hline 10 & 14.853 & 72346 & 0.15 & 51891 & 0.20 & Dichloroacetic acid, decyl ester & 57.10 \\
\hline 11 & 15.042 & 78152 & 0.16 & 55184 & 0.21 & 1-Tetradecanol & 55.00 \\
\hline 12 & 15.098 & 5465560 & 11.08 & 3638303 & 14.17 & E-15-Heptadecenal & 55.05 \\
\hline 13 & 15.167 & 358390 & 0.73 & 251796 & 0.98 & Nonadecane & 57.10 \\
\hline 14 & 15.233 & 121518 & 0.25 & 58454 & 0.23 & 1-Dodecene, 2-Ethyl- & 70.10 \\
\hline 15 & 16.825 & 1774683 & 3.60 & 799656 & 3.11 & Hexadecanoic acid & 73.05 \\
\hline 16 & 17.154 & 5508171 & 11.17 & 3234728 & 12.60 & 1-Heneicosanol & 57.05 \\
\hline 18 & 18.490 & 2148503 & 4.36 & 899849 & 3.50 & Methyl octadeca-9,12-Dienoate & 67.05 \\
\hline 19 & 18.533 & 639984 & 1.30 & 284065 & 1.11 & 22-Tricosenoic acid & 55.05 \\
\hline 20 & 18.583 & 435018 & 0.88 & 159227 & 0.62 & Tetraethylene glycol, monobutyl ether & 57.05 \\
\hline 21 & 18.730 & 274213 & 0.56 & 158768 & 0.62 & Octadecanoic acid & 73.05 \\
\hline 22 & 19.029 & 4633592 & 9.40 & 2745804 & 10.69 & 1-Heneicosanol & 57.05 \\
\hline 23 & 19.075 & 218168 & 0.44 & 158471 & 0.62 & Hexadecane & 57.05 \\
\hline 24 & 20.367 & 510095 & 1.03 & 334653 & 1.30 & O O'-Biphenol, 4,4',6,6'-Tetra-T-Butyl- & 57.05 \\
\hline 25 & 20.463 & 198896 & 0.40 & 109773 & 0.43 & $\begin{array}{l}\text { Cyclopropaneoctanoic acid, 2-[[2-[(2-ethylcyclopropyl) } \\
\text { methyl]cyclopropyl]methyl]-, methyl ester }\end{array}$ & 67.05 \\
\hline 26 & 20.812 & 3446566 & 6.99 & 1825058 & 7.11 & n-Tetracosanol-1 & 57.05 \\
\hline 27 & 20.858 & 157311 & 0.32 & 113330 & 0.44 & Pentadecane & 57.05 \\
\hline 28 & 22.053 & 238723 & 0.48 & 106657 & 0.42 & Hexadecanoic acid, 2-hydroxy-1-(hydroxymethyl)ethyl ester & 57.05 \\
\hline 29 & 23.117 & 1923043 & 3.90 & 829324 & 3.23 & Eicosyl trifluoroacetate & 57.05 \\
\hline 30 & 31.844 & 205298 & 0.42 & 80125 & 0.31 & Docosyl trifluoroacetate & 57.05 \\
\hline 31 & 35.321 & 941280 & 1.91 & 218643 & 0.85 & Dehydroergosterol 3,5-dinitrobenzoate & 69.10 \\
\hline 32 & 36.267 & 2766652 & 5.61 & 260549 & 1.01 & Ergosterol & 69.10 \\
\hline 33 & 36.667 & 2650584 & 5.38 & 534458 & 2.08 & Ergosta-7,22-Dien-3-ol, (3.Beta.,22E)- & 69.10 \\
\hline
\end{tabular}

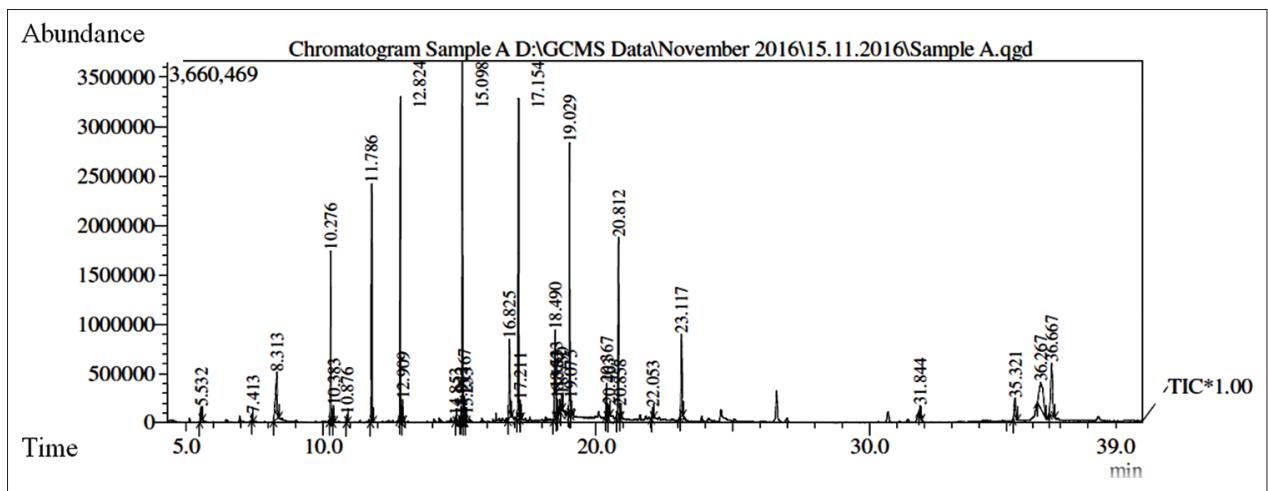

Fig. 2: Gas chromatography-mass spectrometry chromatogram of chloroform extract of Lycoperdon pyriforme

potentiality. Chemicals compounds such as sterol derivatives $(S)$ 23-hydroxylanostrol, ergo-sterol $\alpha$-endoperoxide, ergosterol 9,11-dehydroendoperoxide and ((23E)-lanosta-8,23-dien-3ß,25-diol), volatile compounds (3-octanone, 1-octen-3-ol and (Z)-3-octen-1-ol), and an unusual amino acid such as lycoperdic acid have been identified from Lycoperdon perlatum fruit bodies $[9,10]$. The study represents a primary account of various bioactive compounds in the chloroform extract and a detailed study can be carried out for the isolation and purification of specific compounds for further application in the chemical industry.

\section{CONCLUSION}

Wild mushrooms growing naturally produce a large number of secondary metabolites which impart lots of medicinal values to them. The present work was carried to understand various bioactive compounds present in the chloroform extract of L. pyriforme. A total of 33 compounds have been identified by GC-MS analysis and most of the compounds obtained were those with antimicrobial potentiality. This suggests their importance and potential application in the field of pharmaceutical research.

\section{CONFLICTS OF INTEREST}

The authors declare that they have no conflicts of interest.

\section{REFERENCES}

1. King TA. Mushrooms, the ultimate health food but little research in U. S to prove it. Mush. News 1993;41:29-46.

2. Benedict RG, Brady LR. Antimicrobial activity of mushroom metabolites. J Pharmacol Sci 1972;6:1820-2.

3. Anke T. Basidiomycetes: A source for new bioactive secondary 
metabolites. Prog Ind Microbiol 1989;27:51-66

4. Suay I, Arenal F, Asensio FJ, Basilio A, Cabello MA, Diez MT, et al. Screening of Basidiomycetes for antimicrobial activities. Antonie Van Leeuwenhoek 2000;78:129-39.

5. Yang JH, Lin HC, Mau JL. Antioxidant properties of several commercial mushrooms. Food Chem 2002;77:229-35.

6. Zoberi MH. Tropical Macrofungi. London: MacMillan Publishers; 1972.

7. Buswell JA, Chang ST. Edible mushrooms: Attributes and applications. In: Chang ST, Buswell JA, Miles PG, editors. Genetics and Breeding of Edible Mushrooms. Philadelphia, PA: Gordon and Breach Scientific
Publishers; 1993. p. 297-394.

8. Mohanan C. Macrofungi of Kerala. Peechi, Kerala: Kerala Forest Research Institute; 2011. p. 670.

9. Lamotte J, Oleksyn B, Dupont L, Dideberg O, Campsteyn H, Vermeire $\mathrm{M}$, et al. The crystal and molecular structure of 3-[(5S)-5carboxy-2-oxotetrahy-drofur-5-yl]-(2S)-alanine (lycoperdic acid). Acta Crystallogr B Struct Crystallogr Cryst Chem 1978;34:3635-8.

10. Szumny A, Adamski M, Winska K, Maczka W. Identification of steroid compounds and essential oils from Lycoperdon perlatum. Przem Chem 2010;89:550-3. 